\title{
Flipped Classroom of Ecological Literature under the Background of Environmental Crisis*
}

\author{
Xia Zhang \\ College of Humanities \\ Tianjin Agricultural University \\ Tianjin, China
}

\author{
Jingyuan Xie \\ College of Humanities \\ Tianjin Agricultural University \\ Tianjin, China
}

\begin{abstract}
Since the establishment of ecological literary criticism, under the background of the global ecological crisis, the teaching and research on ecological literature has been greatly concerned; at the same time along with the development of electronic technology and the improvement of information technology, flipped classroom as a new and effective teaching method has been greatly supported by the educators both at home and abroad. However, no teaching cases combining ecological literature and flipped classroom has been recorded in China until now. The analysis of the questionnaire of college students shows that flipped classroom of ecological literature is warmly supported by college students, so flipped classroom of ecological literature by interpreting literary works and transferring Chinese and foreign ecological criticism can improve college students' ecological consciousness and ecological aesthetics, and has positive significance.
\end{abstract}

Keywords-ecological literature; flipped classroom; ecological aesthetics; higher education

\section{INTRODUCTION}

In the postindustrial era, the whole world is facing a more serious environmental crisis than the industrial era. In the face of the worldwide environmental crisis, the United Nations put forward the concept of green development in 2002. In 2012, green development first appeared in the eighteenth report of the Communist Party of China [1]. In the face of environmental crisis, the discussion of ecological ethics and ecological literature creation and criticism has become an important school of humanities circles at present. How to deal with the environmental crisis is not only the target of natural scientific research, but also the focus of attention of the humanities. Since humanities education especially the ecological ethics and cultural education has become an important channel to improve people's awareness of ecological protection, ecological literature creation has become an important carrier of communication on Ecological Ethics and culture in Colleges and universities between China and abroad. With the popularization of electronic devices, mobile phones, iPad and communication platform, basing on the blog, excellent courses and micro lessons, the flipped classroom is more and more accepted by educators, and it is also a teaching mode that will bring life

*Scientific research project of Tianjin Municipal Education Committee "2017SK091"Design and practice of the ecological literature flipped classroom under the background of environmental crisis" and vitality to the eco literature course. At present, teaching results reflecting the combination of ecological literature and flipped classroom have not been published in China, but flipped classroom of ecological literature by interpreting literary works and transferring Chinese and foreign ecological criticism can improve college students' ecological consciousness and ecological aesthetics, and has positive significance.

\section{ECOLOGICAL ETHICS AND ECOLOGICAL LITERATURE}

The environmental crisis has made the earliest industrialized countries such as England think about the ecological ethics. The discussion about the creation of ecological literature and the ethics of ecology accumulated and rich ecological literature texts and ecological philosophy with global influence were established. The works of Hardy presented the misappropriation of modern industry and the loss of people's spiritual home in the British countryside; Laurence's novels revealed people and natural alienation brought by industrialization. After World War II, Britain passed a series of bills to convey the idea of ecology to the public and improved the understanding of environmental problems [2]. The treatment of environmental problems in Britain has benefited from the change of western traditional human centered ethical ideas and the establishment of an ecological view of harmony between man and nature.

Ecocriticism has promoted public awareness of ecological protection. Williams Raymond, a literary critic, put forward the ecological crisis brought by urbanization and capitalist development as early as The country and the city (1973), warning the public to pay attention to "nature"; The ecological analysis of the British Romantic poetry by Laurence Buell represents the earliest sound of British Ecological Criticism; in 1991, Jonathan Bate's Romantic Ecology opened a new era of the British Ecological criticism; Norway philosopher Arne Naess proposed a "deep ecology", American critics put forward "environmental justice". In 2002 the term of "ecological criticism" was written into the search words by the U.S. National Library.

Since ancient times, China has advocated the harmonious relationship between man and nature [3]. The concept of "harmony between man and nature" put forward by Confucians has something in common with the Taoist philosophy of ecology [4]. Modern China's first focus on 
ecological literary criticism dated back to the concern on the contemporary Soviet Union ecological literature by $\mathrm{Xu}$ Xianxu in 1987 [5]; the Xiamen research team of ecological literature was founded in 2004 and became the most powerful domestic ecological literature research team, and at the same time Shandong University and the Capital University of Economics and Business and other colleges and universities all dedicated to the study of nature writing; "Yanoda ecological literature award" founded in 2015 has become one of the Chinese currently influential social ecological literature award. Although the contemporary ecoliterature creation in China is relatively poor compared to English eco-literature, the achievements of research on English eco-literature are of great significance to the construction of ecological values and ecological civilization in China.

\section{ECOLOGICAL LITERATURE COURSE AND FLIPPED ClASSROOM}

With the development of information industry, richness and convenience of personal terminal, under the the influence of American teaching mode, Chinese teaching mode is also quietly changing, using multimedia, excellent courses, MOOC and micro lessons to promote teaching reform. Reverse classroom, also known as "flipped classroom", has become a new teaching mode which is developed on the basis of micro lessons and MOOC, using public teaching resources and modern interactive terminals, and has remarkable effect in practice.

In 2000, Maureen Lage in the United States in the paper "Inverting the Classroom: A Gateway to Creating an Inclusive Learning Environment", they introduced the "flip teaching" mode and their achievements in University of Miami's "introductory economics". In 2011 American teacher Sahlman Khan first put forward the concept of "flipping" by using the teaching video, classroom activities and constructing learning environment to improve teaching environment, which is widely accepted in American high school and college chemistry, medical courses [6]. The "flipped classroom" is adopted in countries including USA, Canada, Australia, China and other countries. American Higher Education Association proposed seven principles of effective learning of undergraduate physics; Harvard University chose peer learning; University of Washington used instant teaching; The University of British Columbia in Canada combined the above two methods in biological computer lessons; the related research of Monash University also disclosed the peer coaching has a similar effect in the humanities; Canada undergraduate class (250 people) of the physics using the "flipped classroom" also received good results. In practice, the instructors actively explore the teaching mode of "flipped classroom", and improve the students' knowledge cognition and internalization effect.

China's Ministry of education in the long term education reform and development plan (2010-2020) also made clear to make full use of the high quality education resources and build information learning environment with learning and education model innovation as the core concept of educational reform. "Flipped classroom" and practice get accepted by young teachers aged 30 to 40 in China. On the basis of the teaching model constructed by Talbert in the United States, Zhang Jinlei put forward a teaching model of "problem based learning". But the flipped classroom still in the imitation and learning process, comparing the traditional teaching advantages it also needs to further improve the hardware and software conditions, enrich the teaching materials and teaching resources, change the current single teaching content form and focus on the use of a multidisciplinary perspective on information technology and curriculum integration [7]. Through the analysis of 20102017 related papers in China Journal Net, the theoretical research of flipped classroom is more than that of empirical research. Domestic humanities are more likely to accept the teaching mode of "flipped classroom", while the related study on ecological literature flipped classroom is not yet available. In the preface of The ecology of literature -- the reading of British and American Ecological Literature, Nangong Meifang especially mentioned that its teaching material can be applied to the "flipped classroom" [8].

Under the background of the construction of ecological civilization, ecological literature is not only the focus of scientific research in Colleges and universities, but starting the ecological literature courses in Colleges and universities by use of "flipped classroom" teaching mode, to build student centered activities teaching concept, integrate ecological civilization and the ecological ethics in higher education, is the selection under the background of global environmental crisis.

\section{QUESTIONNAIRE ON THE FLIPPED CLASSROOM OF ECOLOGICAL LITERATURE}

Design and practice of ecological literature is based on the flipped classroom education theory and research data [9], so the questionnaire survey of college students on micro lessons design, online learning platform, status of ecological literature course and the influence of the consciousness of ecological protection, design and influence of ecological literature courses, pays an important basis for the Ecological Literature Classroom Teaching.

\section{A. Questionnaire Design}

Based on reading and analyzing CNKI related literatures in China and combining with the goal of flipping classroom teaching on ecologic literature, 20 questions were designed in this questionnaire. They are all single questions, and the two-dimensional code is formed by the help of Questionnaires Online. Among them, 1-6 questions are about students' online learning, 7-11 about classroom interaction teaching, 12-17 about the establishment and value of ecoliterature courses, and the last three topics are about personal basic information, which involve gender, grade and major. The questionnaire was conducted among the students in English Majors of grade 2015 and grade 2016 in the College; the questionnaire was done during the winter vacation, so in order to ensure the validity of the questionnaire, the questionnaire set up a condition that 60 seconds to complete the questionnaire is invalid, as a result 50 valid questionnaires were collected, including 30 from grade 2016, 
20 from grade 2015 . The 50 copies of valid questionnaires were analyzed by SPSSAU statistics with different variables.

\section{B. Questionnaire Spss Data Analysis}

The frequency analysis of several questions which are most closely related to the flipped classroom of ecological literature shows that:

TABLE I. FREQUENCY ANALYSIS OF QUESTIONS 12-17

\begin{tabular}{|c|c|c|c|}
\hline Questions & Answers & Frequency & $\%$ \\
\hline \multirow[b]{2}{*}{$\begin{array}{c}\text { Do you think there } \\
\text { should be eco - } \\
\text { literature courses } \\
\text { during the } \\
\text { University? }\end{array}$} & Yes & 48 & 96 \\
\hline & No & 2 & 4 \\
\hline \multirow{3}{*}{$\begin{array}{l}\text { If you don't support } \\
\text { an ecological } \\
\text { literature course, } \\
\text { what do you think is } \\
\text { the most important } \\
\text { reason? }\end{array}$} & $\begin{array}{c}\text { not interested } \\
\text { in ecological } \\
\text { literature }\end{array}$ & 7 & 14 \\
\hline & $\begin{array}{l}\text { not related to } \\
\text { the major }\end{array}$ & 30 & 60 \\
\hline & $\begin{array}{l}\text { no time to } \\
\text { study }\end{array}$ & 13 & 26 \\
\hline \multirow{3}{*}{$\begin{array}{c}\text { If you have an } \\
\text { ecological literature } \\
\text { course, do you think } \\
\text { how many hours a } \\
\text { week is acceptable? }\end{array}$} & 2 hours & 37 & 74 \\
\hline & 3 hours & 8 & 16 \\
\hline & 4 hours & 5 & 10 \\
\hline \multirow{2}{*}{$\begin{array}{c}\text { Do you support } \\
\text { discussion in the } \\
\text { ecological literature } \\
\text { course? }\end{array}$} & Yes & 45 & 90 \\
\hline & No & 5 & 10 \\
\hline \multirow[t]{2}{*}{ Your grade } & sophomores & 30 & 60 \\
\hline & Juniors & 20 & 40 \\
\hline \multicolumn{2}{|c|}{ Total } & 50 & 100 \\
\hline
\end{tabular}

It can be seen from the above "Table I" that the ratio of "yes" about the selection of ecological literature courses in the sample is $90 \%$. The statistics show that all of the students from grade 2015 support the course of ecological literature during the University, and only $6.7 \%$ of the grade 2016 have chosen "No". $74 \%$ of the samples chose " 2 hours" ecological literature courses weekly. From the distribution point of view, most of the samples are "yes" and support the organizational form of the class in discussion in the ecological literature course, with a total of 45 , accounting for $90 \%$.

The development of flipped classroom is based on the digital information platform. This questionnaire survey involves the frequency analysis of online courses and network platforms.

As shown in "Table II", in the 50 valid questionnaires, the proportion of "1-2 times per week" online course was $54 \%$, and the proportion of never using online class samples was $40 \%$. From the perspective of whether they are willing to accept ten minutes micro video (micro lesson) to preview professional courses, there is a relatively large number of samples of "accepted", with the proportion $68 \%$, and the proportion of samples to try is $32 \%$. It is believed that most of the most influential factors in the study of micro class are "lack of teacher guidance and lack of feedback of problems", with the proportion of $38 \%$. The proportion of "being useful" was $40 \%$ in the sample.
TABLE II. FREQUENCY ANALYSIS OF QUESTIONS 1-6

\begin{tabular}{|c|c|c|c|}
\hline Questions & Answers & Frequency & $\%$ \\
\hline \multirow{3}{*}{$\begin{array}{c}\text { Do you often watch } \\
\text { online courses such as } \\
\text { open class, Khan college, } \\
\text { TED or mousse? }\end{array}$} & never & 20 & 40 \\
\hline & $\begin{array}{c}\text { once or twice a } \\
\text { week }\end{array}$ & 27 & 54 \\
\hline & 3-4 times a week & 3 & 6 \\
\hline \multirow{3}{*}{$\begin{array}{l}\text { Would you like to take } \\
\text { micro lesson about ten } \\
\text { minutes for a pre-class } \\
\text { preview of a professional } \\
\text { course? }\end{array}$} & accept & 34 & 68 \\
\hline & can try & 16 & 32 \\
\hline & not to accept & 0 & 0 \\
\hline \multirow{4}{*}{$\begin{array}{l}\text { What do you think is the } \\
\text { biggest impact factor in } \\
\text { the use of micro class } \\
\text { learning? }\end{array}$} & $\begin{array}{c}\text { net speed affects } \\
\text { learning }\end{array}$ & 9 & 18 \\
\hline & $\begin{array}{c}\text { lack of teacher } \\
\text { guidance and } \\
\text { feedback. }\end{array}$ & 19 & 38 \\
\hline & $\begin{array}{l}\text { lack of relevant } \\
\text { resources for } \\
\text { deep study } \\
\end{array}$ & 14 & 28 \\
\hline & $\begin{array}{l}\text { no forum or the } \\
\text { discussion not } \\
\text { warm }\end{array}$ & 8 & 16 \\
\hline \multirow{4}{*}{$\begin{array}{c}\text { Do you think micro } \\
\text { courses in professional } \\
\text { courses will help you in } \\
\text { your study? }\end{array}$} & very helpful & 13 & 26 \\
\hline & some help & 20 & 40 \\
\hline & little help & 13 & 26 \\
\hline & without help & 4 & 8 \\
\hline \multicolumn{2}{|l|}{ Total } & 50 & 100 \\
\hline
\end{tabular}

\section{Results Analysis}

Based on the survey results and analysis of the previous questionnaire [10], this paper put forward the flipped classroom teaching of ecological literature with the help of the online teaching platform such as micro class. The respondents were selected from sophomores and juniors in the English major, and completed the 50 valid questionnaires during the Spring Festival holiday of 2018. Statistics of effective questionnaire data showed that the ecological literature curriculum is unfamiliar to English major students, but they affirmed the significance and value of ecological literature curriculum in higher education stage, showed great enthusiasm and almost all of them support ecological literature course. When it comes to the problem of classroom participation and teacher's role, more than half of the respondents think that teachers should be "organizers and participants of classroom activities". They support independent learning and interaction activities. In the context of the popularization of smart phones and online browsing learning, they show positive cooperation and support for developing online classroom teaching. From the perspective of learners, they welcome the study and discussion of ecoliterature in the stage of higher education with the help of information platform and digital technology, which is a favorable basis for further large-scale related research and ecological literature flipped classroom teaching practice.

\section{CONCLUSION}

Through the analysis of the ecological literature and the related research of flipped classroom data, with the help of the survey results, the flipped classroom of ecology literature is proved to be an effective way to raise students' ecological aesthetics and enhance people's awareness of environmental protection under the background of the current 
environmental crisis. It is an important means to promote the realization of the humanistic education in modern education by combining the research results of Humanities and modern science and technology in the new period.

"Flipped classroom" can obtain more lively and vivid teaching environment than the traditional classroom by strengthening the interaction and communication between teachers and students, so as to change the traditional teachercentered mode, and it is suitable for the psychological development of students with the autonomous learning ability in the new period. Ecological literature, with "flipped classroom" teaching model as the carrier, is in line with the goal of ecological culture and ecological morality education in the training of talents in Colleges and universities. Through the appreciation of eco-literature works, it can promote the cognition of positive ecological philosophy, and provide a textual basis and reference for the cultivation of talents' Ecological Consciousness under the background of environmental crisis. Under the increasingly strengthened international communication environment, the "flipped classroom" of eco-literature will become a platform for communication at home and abroad, and promote the growth of scientific research force, expand the field of vision of teachers, and promote the exploration and development of interdisciplinary teaching and research methods.

The establishment of eco-literature course at undergraduate stage is a breakthrough in domestic higher education. It requires learners to have broad social vision, social responsibility and basic cognition of ecological culture. This research is an attempt of undergraduate education. The flipped classroom needs material foundation of software and hardware, and the construction of information platform needs professional maintenance. Therefore, we need to integrate the resources advantages of multi-disciplinary universities, reflecting the characteristics of interdisciplinary research. The process of the localization of the "flipped classroom" is the result of the coordination of many factors. In particular, it needs a long time to strengthen the construction of the "flipped classroom" teaching evaluation mechanism. Although many challenges are still ahead, the previous research results lay the foundation for the teaching design and practice of the ecological literature flipped classroom in this university.

\section{REFERENCES}

[1] Zhao Gengke, Shi Xiaoni. Green development concept in new economic norm of China. China high-tech enterprises, 2016 (18): 1-5.

[2] Zhang Yongmin. The status of the British ecosystem, challenges and countermeasures. Environmental protection, 2012 (4): 73-75.

[3] Zhang Liwen. The argument of heaven and man-Confucianism and ecological civilization. Beijing: People's publishing house, 2013.

[4] Wang Sufen, Ding Quanzhong. Lao Tzu philosophy in the ecological context. Beijing: People's publishing house, 2016.

[5] Ji Xiuming. Ecological literature review in recent thirty years of China. Journal of Liaoning University (PHILOSOPHY AND SOCIAL SCIENCES), 2009 (1): 25-29.

[6] Zhang Jinlei. An analysis of the key factors in the "flipped classroom" teaching model. Chinese distance education, 2013,10 (12): 59-64.
[7] Guan Siyi. Research overview of Flipped classroom home and abroad in late five years. Central China University Journal, 2016, 23 (3): 105-108.

[8] Nangong Meifang, Wei Wen. The ecology in Literature -- reading of British and American ecological literature. Beijing: Peking University press, 2015.

[9] Chickering A.W., Gamson Z.F.. Seven principles for good practice in undergraduate education. The Wingspread Journal, 1987.9 (2): 1-11.

[10] Zhao Ting. Investigation and study of college students' views on English micro courses. Shijiazhuang: Hebei Normal University, 2016. 